\title{
Corrosion Behaviour of Friction Stir Welded Aluminium Alloys: Unpredictability and Protection
}

\author{
Uyime Donatus* \\ Department of Metallurgical and Materials Engineering, Nigeria
}

*Corresponding author: Uyime Donatus, Department of Metallurgical and Materials Engineering, Akure-PMB 704, Akure, Nigeria

Submission: 監 October 01, 2017; Published: 監 November 29, 2017

\begin{abstract}
The corrosion susceptible regions in friction stir weldments of aluminium alloys are largely unpredictable. Several factors dictate the undesirable susceptibility of an $\mathrm{Al}$ alloy friction stir weldment. A change in temper or processing parameters can significantly alter the corrosion behaviour of an $\mathrm{Al}$ alloy weldment. Pronounced zonal heterogeneities induced by the welding process causes increased corrosion rate of the susceptible region due to galvanic coupling with the more noble regions. To prevent this, different protection methods and techniques have been employed and are currently being developed. Laser surface melting, post-weld heat treatment, micro-arc oxidation, application of corrosion resistant material, conventional anodizing, and pre-sputter deposition prior to anodizing have all been shown to improve the corrosion resistance of friction stir weldments of different Al alloys.
\end{abstract}

Keywords: Friction stir welding; Aluminium alloys; Corrosion; Corrosion protection; Anodizing

\section{Introduction}

Globally, conscious efforts are being made to reduce $\mathrm{CO}_{2}$ emission and current developments are increasingly inclined towards green technology. Thus, in the transport industry, lightweight materials and alloys, which encourage lesser fuel or lesser energy consumption compared with the conventionally used ones, are constantly being sought. Because of this, aluminium alloys are of significant importance as they offer light-weightedness with good strength to weight ratio and relatively good corrosion resistance.

In assembling parts, welding is often employed. Amongst the many welding techniques available, friction stir welding technique has evolved to becoming one of the best options. Currently, friction stir welding employs stationery, heavy and non-flexible machinery. But flexibility and portability are desired, and researches are on-going to develop a portable and flexible friction stir welding machine [1-3]. Despite this shortcoming, friction stir welding is arguably the best welding technique for $\mathrm{Al}$ alloys. This is because it is a solid-state welding technique, and most defects associated with liquid-solid transformation, as obtained in fusion welding techniques, are avoided. However, like every other welding process, friction stir welding introduces different zones possessing distinct metallurgical and microstructural characteristics in a weldment. This results in pronounced variations in mechanical properties and chemical/electrochemical responses across the weldment.

For the wrought $\mathrm{Al}$ alloys with tempers like the 0 temper, the effect of friction stir welding induced microstructural and metallurgical variations on the weldment may be minimal on the properties. As an example, for a friction stir welded AA5083-0 alloy [4], the microhardness values across the weld zones are more or less in the same range with that of the parent material (PM). Nonetheless, the corrosion susceptibilities in the zones can be different due to the preferential precipitation of $\beta\left(\mathrm{Al}_{3} \mathrm{Mg}_{2}\right)$ phase at the grain boundaries, at regions where the peak temperature is high enough to cause the precipitation of this phase; which can be as low as $60{ }^{\circ} \mathrm{C}[5,6]$. With regards to microhardness, a friction stir welded AA5083-H alloy shows pronounced variation in the microhardness values across the weld zones [7] compared with the weldment of the AA5083-0 alloy earlier mentioned. This pronounced variation is also true for wrought heat treatable aluminium alloys, especially in their peak aged tempers. And the corrosion behaviour and mechanism can be very different from zone to zone.

In most other alloy systems, the regions that are most susceptible to corrosion in their weldments are generally predictable. A good example is austenitic stainless steels, where weld decay-which occurs due to chromium depletion by the formation of chromium carbides in the heat affected zone (HAZ)-is a common feature and it is generally known by professionals and researchers in the field. In the case of $\mathrm{Al}$ alloys, the corrosion most susceptible regions and the forms of corrosion are not predictable. It is widely varied and depends on the composition, thermo-mechanical treatments, grain sizes, types of precipitates formed, composition and characteristics of the near surface deformed layer and other alloy- 
history-dependent factors. In addition to alloy-history-dependent factors, the welding tool design and processing parameters also affect the corrosion behaviours of friction stir weldments. This is largely because they influence the degree of mixture, peak temperature attained, temperature gradient and heat distribution. For a 2xxx (Al-Cu-Mg) series alloy, an example of a combination of some of these factors can be found in the work of Jariyaboon [8] where they investigated the effects of welding parameters on the corrosion behaviour of welded AA2024-T351 alloy. It was revealed that rotation speed controlled the location of the attacked region in the weldment. For low rotation speed, the attack was mainly in the stir zone and the form of attack was intergranular; whereas for higher rotation speed the corrosion attack was mainly in the heat affected zone. The latter is in agreement with the work of Bousquet [9], where they stated that the susceptibility in the HAZ was due to the presence of continuous lines of the $\mathrm{S}^{\prime}\left(\mathrm{S}-\mathrm{Al}_{2} \mathrm{CuMg}\right.$ ) phase at the grain boundaries. Similarly, Kang [10] revealed that the density and degree of pitting corrosion were slightly larger in the shoulder region of an AA2024-T3 friction stir weld and noted that with optimum welding parameters the corrosion resistance of the weldment can be improved. For a $6 \mathrm{xxx}$ (Al-Mg-Si) series alloy, an example is seen in the work of Esmaily [11]. They revealed that for an AA6005-T6 alloy friction stir weldment, the stir zone (SZ) was susceptible to corrosion; however, the extent of pitting corrosion susceptibility in the stir zone reduced with number of friction stir passes, but with increasing number of passes, significant pitting corrosion was induced in the HAZ of the weldment. The corrosion susceptibilities of the 6xxx series alloys are often associated with the $\beta\left(\mathrm{Mg}_{2} \mathrm{Si}\right)$ phase [5]. Representative examples of friction stir weldments of the $7 \mathrm{xxx}(\mathrm{Al}-\mathrm{Zn}-\mathrm{Mg})$ series alloys show that the thermo-mechanically affected zones (TMAZs) adjacent to the weld nuggets were the corrosion most susceptible regions [12,13], and this was attributed to the activities of $\eta / \eta^{\prime}\left(\mathrm{Mg}_{2} \mathrm{Zn}\right)$ phase.

Within the last two decades, new sets of light-weight $\mathrm{Al}-\mathrm{Cu}-\mathrm{Li}$ alloys have evolved. These alloys are often referred to as the $3^{\text {rd }}$ generation $\mathrm{Al}-\mathrm{Li}$ alloys. The presence of $\mathrm{Li}$ in these alloys increases their moduli of elasticity and decreases their weight significantly [14]. The Al-Cu-Li alloys are intended for aerospace application and researches are currently on-going to further understand the behaviours of this group of alloys [14]. The corrosion behaviours of the friction stir weldments of a few $3^{\text {rd }}$ generation $\mathrm{Al}-\mathrm{Cu}$-Li alloys have been reported. In 2011, Proton [15] investigated the influence of post-weld heat treatment on the corrosion behaviour of a new generation AA2050 Al-Cu-Li alloy weldment. They reported that the HAZ was the most susceptible region when the weldment was not subjected to post-weld heat treatment and the form of attack was intergranular. Most recently, Zhang [16], on their work on the corrosion behaviour of 2A97 Al-Cu-Li alloy friction stir weldment, reported that the most susceptible region to corrosion was the TMAZ of the weldment and this was attributed to the presence of high population density of T1 phase in the TMAZ.

Whilst noting that the studies of the corrosion behaviours of the weldments discussed above were conducted in different environments, obviously, it is difficult to predict the corrosion susceptibilities and corrosion forms in friction stir weldments of wrought Al alloys. Except for the fact that the susceptible regions are mostly the SZ, TMAZ or HAZ and not the PM. However, there are also experimental findings revealing that the PM is the most susceptible region in certain $\mathrm{Al}-\mathrm{Cu}-\mathrm{Li}$ alloys.

On the contrary, it is much easier to predict the corrosion susceptibilities of friction stir welded dissimilar aluminium alloys. Generally, outside the welding tool domain, the corrosion characteristics of the individual alloys tend to be comparable to that in the similar weld of the alloy, except for cases of significant potential differences between the two alloys. Even at that, the galvanic effect on the corrosion behaviour of the individual alloy, outside the tool domain, will be mostly governed by the conductivity of the electrolyte. In the tool domain, the more active alloy corrodes preferentially with the attack spreading into the active alloy's rich zone from the galvanic boundary of the two alloys or their rich zones.

It is also important to state that in many friction stir welds, boundaries between the materials from the advancing side and the materials from the retreating side, where mixtures do not occur, often exist [6,17-19]. Reports from microstructural examinations reveal the formation of intermetallic particles along these boundaries when dissimilar alloys are involved [5]. This raises concern over both the mechanical integrity and the corrosion resistance of such weldments. With regards to corrosion, preferential attack occurs at these boundaries in dissimilar $\mathrm{Al}$ alloy weldments.

Evidently, corrosion protection of friction stir weldments of $\mathrm{Al}$ alloys is very important. Paglia \& Buchheit [20] once suggested modification of the microchemistry during friction stir welding by the addition of elements like Li. Except there is a special way of ensuring equal distribution (which is difficult), this process can lead to the introduction of more micro-galvanic cells in the weld, and macro-galvanic cells in the weldment as a whole.

Martin \& Bolser [7] stated that it is possible to improve the corrosion resistant of a friction stir weldment by applying a corrosion resistant layer over one or both surfaces of the materials to be joined. By so doing, the corrosion resistant materials form metallurgical bond with the plasticized material during welding to form a corrosion resistant joint. By adapting laser melting technique Padovani [21] revealed that the method was able to reduce the depth of attack in an AA7449-T7951 alloy. However, they also revealed that the method did not particularly influence the breakdown potential but reduced the cathodic reactivity. In a similar way, Kalita [22] also showed that laser melted friction stir weldment of 2024-T351 alloy exhibited improved corrosion resistance. It has also been shown that micro arc oxidation/ coatings improves the corrosion resistance of friction stir welded $\mathrm{Al}$ alloys $[23,24]$. Beneficial heat treatments have also been reported for dissimilar weld of AA7075 and AA2024 [25,26].

Most of the mentioned techniques and methods are good corrosion prevention/control techniques; however, conventional anodizing is usually employed for Al alloys in most industries. Thus, it 
is also important to consider the corrosion protection of weldments by anodizing. This was the basis behind the investigations on areas of concern in an anodized dissimilar friction stir weld, anodizing behaviour in friction stir weldments of dissimilar $\mathrm{Al}$ alloys, and effect of prior sputter deposition on an anodized dissimilar friction stir weldment of AA5083-0 and AA6082-T6 alloys by Donatus $[6,18,19]$. They reported that anodizing creates some areas of concern in friction stir weldments of dissimilar Al alloys. The first problem was the uneven oxidation across the weldment, and the second problem was the boundary dissolution at the interface between the materials from the advancing side and the materials from the retreating side. Having identified these problems, they developed a method that prevented the boundary dissolution and prevented or significantly minimised the differential oxidation across the weldment during anodizing [6]. This was achieved by pre-sputtering a thin layer of $\mathrm{Al}$ on the surface of the weldment prior to anodizing. It was also further proven that the adopted method improved the corrosion resistance of the dissimilar weldment significantly [19]. However, more work is required to optimise the process to an industrially acceptable standard.

\section{Conclusion}

The following conclusions can be drawn.

a. Friction stir welding introduces zonal heterogeneities in $\mathrm{Al}$ alloy weldments. This zonal heterogeneity increases the corrosion susceptibilities of the weldments.

b. The regions of corrosion susceptibilities in Al alloy weldments are highly unpredictable and can significantly vary for an alloy of the same composition with variations in temper conditions and welding parameters.

c. Different approaches have been found to improve the corrosion resistance of $\mathrm{Al}$ alloy friction stir weldments, which include conventional anodizing, micro-arc oxidation, laser surface melting and post-weld heat treatment. However, improvements and standardization of different developed methods are required.

\section{References}

1. Nunn ME (2007) Review of systems for portable friction stir welding equipment-Industrial Member Report 851a/2007.

2. (2017) Portable friction stir welding technology for aluminum fabrication. SBIR.gov.

3. (2014) Portable friction stir welding machine. Tech briefs.

4. Behnagh RA, Besharati Givi MK, Akbari M (2012) Mechanical properties, corrosion resistance, and microstructural changes during friction stir processing of 5083 aluminum rolled plates. Mater Manuf Process 27(6): 636-640.

5. Donatus U, Thompson GE, Zhou X, Wang J, Cassell A, et al. (2015) Corrosion susceptibility of dissimilar friction stir welds of AA5083 and AA6082 alloys. Mater Charact 107(2015): 85-97.

6. Donatus U, Thompson GE, Zhou X (2015) Anodizing behavior of friction stir welded dissimilar aluminum alloys. J Electrochem Soc 162(2015): C657-C665

7. Martin RL, Bolser DR (2000) Integral corrosion protection of friction welded joints.
8. Jariyaboon M, Davenport AJ, Ambat R, Connolly BJ, Williams SW (2007) The effect of welding parameters on the corrosion behaviour of friction stir welded AA2024-T351. Corros Sci 49(2): 877-909.

9. Bousquet E, Poulon-Quintin A, Puiggali M, Devos O, Touzet M (2011) Relationship between microstructure, microhardness and corrosion sensitivity of an AA 2024-T3 friction stir welded joint. Corros Sci 53(9): 3026-3034.

10. Kang J, Fu R, Luan G, Dong C, He M (2010) In-situ investigation on the pitting corrosion behavior of friction stir welded joint of AA2024-T3 aluminium alloy. Corros Sci 52: 620-626.

11. Esmaily M, Mortazavi N, Osikowicz W, Hindsefelt H, Svensson JE (2016) Influence of multi-pass friction stir processing on the corrosion behavior of an Al-Mg-Si alloy. J Electrochem Soc 163(3): C124-C130.

12. Deng Y, Ye R, Xu G, Yang J, Pan Q et al. (2015) Corrosion behaviour and mechanism of new aerospace Al-Zn-Mg alloy friction stir welded joints and the effects of secondary $\mathrm{Al}_{3} \mathrm{ScxZr1-x}$ nanoparticles. Corros Sci 90: 359-374.

13. Wadeson DA, Zhou X, Thompson GE, Skeldon P, Oosterkamp LD, et al. (2006) Corrosion behaviour of friction stir welded AA7108 T79 aluminium alloy. Corros Sci 48: 887-897.

14. Dursun T, Soutis C (2014) Recent developments in advanced aircraft aluminium alloys. Mater Des 56(2014): 862-871.

15. Proton V, Alexis J, Andrieu E, Blanc C, Delfosse J, et al. (2011) Influence of post-welding heat treatment on the corrosion behavior of a 2050T3 Aluminum-Copper-Lithium alloy friction stir welding joint. J Electrochem Soc 158(5): C139-C147.

16. Xinxin Zhang JW, Liu B, Zhou X, Chen Luo FL, Sun Z (2017) Corrosion behavior of friction stir welded 2A97 Al-Cu-Li alloy. Corrosion 9312: 2418.

17. Donatus U, Thompson GE, Zhou X, Wang J, Beamish K (2015) Flow patterns in friction stir welds of AA5083 and AA6082 alloys. Mater Des 83: 203-213.

18. Donatus U, Thompson GE, Morsch S, Tsai I (2016) Areas of concern in an anodised dissimilar friction stir weld of AA5083 and AA6082 aluminium alloys. Trans Inst Met Finish 94(2): 70-75.

19. Donatus U, Thompson GE, Zhou X (2016) Effect of prior sputter deposition of pure aluminium on the corrosion behaviour of anodized friction stir weld of dissimilar aluminium alloys. SMM 123: 126-129.

20. Paglia CS, Buchheit RG (2008) A look in the corrosion of aluminum alloy friction stir welds. Scr Mater 58(4): 383-387.

21. Padovani C, Davenport AJ, Connolly BJ, Williams SW, Siggs E, et al. (2011) Corrosion protection of AA7449-T7951 friction stir welds by laser surface melting with an excimer laser. Corros Sci 53: 3956-3969.

22. Kalita SJ (2011) Microstructure and corrosion properties of diode laser melted friction stir weld of aluminum alloy 2024 T351. Appl Surf Sci 257: 3985-3997.

23. Yang Y, Zhou L (2014) Improving corrosion resistance of friction stir welding joint of 7075 Aluminum alloy by micro-arc oxidation. J Mater Sci Technol 30: 1251-1254.

24. Prasad Rao K, Janaki Ram GD, Stucker BE (2008) Improvement in corrosion resistance of friction stir welded aluminum alloys with micro arc oxidation coatings. Scr Mater 58: 998-1001.

25. Widener CA (2000) Evaluation of post-weld heat treatments for corrosion protection in 2024 and 7075 Aluminum alloys.

26. Widener CA, Burford DA, Kumar B, Talia JE, Tweedy B (2007) Evaluation of post-weld heat treatments to restore the corrosion resistance of friction stir welded Aluminum alloy 7075-T73 vs. 7075-T6. Mater Sci Forum, Volumes 539-543: 3781-3788. 